
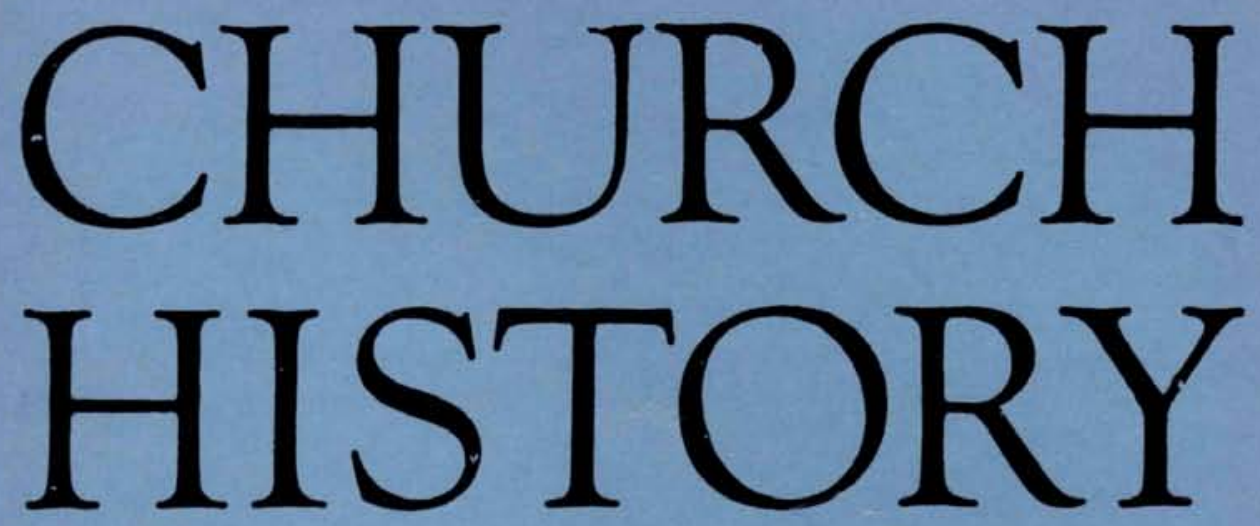

SEPT, 1956

The Importance of Jacques Saurin in the History of Casuistry and the Enlightenment

George L. Mosse

Doctrine and Fellowship: William Channing

Gannett and the Unitarian Creedal Issue

William H. Pease

The Social Gospel and the Trust-busters

Robert R. Roberts

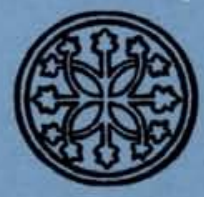

Published by

THE AMERICAN SOCIETY OF CHURCH HISTORY 


\section{THE AMERICAN SOCIETY OF CHURCH HISTORY}

Founded By Philip Schaff, 1888: Reorganized, 1906; Incorporated by ACt Of The Legislature of New York, 1916.

\begin{tabular}{|c|c|}
\hline $\begin{array}{l}\text { Quirinus Breen } \\
\text { H. Shelton Smith .......... Vice-President } \\
\text { Winthrop S. Hudson ..........Secretary } \\
\text { (Colgate-Rochester Divinity School, } \\
\text { Rochester, New York) }\end{array}$ & $\begin{array}{l}\text { Frederick A. Norwood .........Asst. Sec. } \\
\text { Guy S. Klett . . } \\
\text { J. H. Nichols } \\
\text { Frederick A. Norwood }\end{array}$ \\
\hline $\begin{array}{l}\quad \text { OTHER VOTING MEMBI } \\
\text { Ray C. Petry } \\
\text { Sandford Fleming } \\
\text { Sidney E. Mead } \\
\text { Carl E. Schneider }\end{array}$ & $\begin{array}{l}\text { RS OF THE COUNCIL } \\
\text { Leonard J. Trinterud } \\
\text { George H. Williams } \\
\text { Robert T. Handy } \\
\text { Jerald C. Brauer }\end{array}$ \\
\hline $\begin{array}{l}\qquad \text { ADVISORY MEMBERS } \\
\text { Henry B. Washburn } \\
\text { William Walker Rockwell } \\
\text { Winfred E. Garrison } \\
\text { William Warren Sweet } \\
\text { Conrad H. Moehlmann } \\
\text { Frederick W. Loetscher } \\
\text { John T. McNeill } \\
\text { Wilhelm Pauck Massey H. }\end{array}$ & $\begin{array}{l}\text { OF THE COUNCIL } \\
\text { Roland H. Bainton } \\
\text { E. R. Hardy, Jr. } \\
\text { Harold S. Bender } \\
\text { Percy V. Norwood } \\
\text { Kenneth S. Latourette } \\
\text { Matthew Spinka } \\
\text { Cyril W. Richardson } \\
\text { Ernest G. Schwiebert } \\
\text { Shepherd }\end{array}$ \\
\hline
\end{tabular}

Subscription prices are four dollars a year, one dollar and a quarter for single copies. Twenty-five cents a year should be added for foreign countries. Remittances should be made to the order of the American Society of Church History. Subscriptions, renewals, changes of address, claims for missing numbers, orders for single copies of current or back issues should be addressed to Guy S. Klett, Presbyterian Historical Society, 520 Witherspoon Building, Philadelphia 7, Pennsylvania. Claims for missing numbers will be honored without charge if made within within two months following the regular month of publication.

Manuscripts and books for review should be sent to the editorial office, 306 Swift Hall, University of Chicago, Chicago 37, Ill.

The articles in CHURCH HIstoRY are indexed in the International Index to Periodicals.

Microfilm reproductions of CHURCH HistoRy, beginning with Volume XVIII, are available to subscribers and to members of the Society from University Microfilms, 313 North First Street, Ann Arbor, Michigan.

The Publication Office is in Berne, Indiana.

Entered as second class matter March 9, 1934, at the post-office at Berne, Indiana, under the Acts of March 3, 1879. 


\section{CHURCH HISTORY}

Edited by J. H. Nichols and F. A. NoRwood with the cooperation of

Roland Bainton (Divinity School, Ray C. Petry (Divinity School, Duke Yale University) (Divinity Scrsity)

R. Pierce Beaver (Divinity School, Matthew Spinka (Hartford TheoUniversity of Chicago)

Robert Grant (Divinity School, WiLtelm PAUCK (Union Theological University of Chicago) Seminary)

Winthrop S. Hudson (Colgate- John Dillenderger (Divinity School, Rochester Divinity School) Harvard University)

SIDNEY E. Mead (Divinity School, EDWARd A. Dowey, Jr. (McCormick University of Chicago) Theological Seminary)

\begin{tabular}{lll}
\hline VOL. XXV & SEPTEMBER, 1956 & No. 3 \\
\hline
\end{tabular}

\section{TABLE OF CONTENTS}

The Importance of Jacques Saurin in the History of Casuistry and the Enlightenment

George L. Mosse

Doctrine and Fellowship: William Channing Gannett

and the Unitarian Creedal Issue

William H. Pease

The Social Gospel and the Trust-Busters

Robert R. Roberts

Surveys of Recent Literature

British Church History Winthrop S. Hudson

EAstern Orthodox History Matthew Spinka

Doctoral Dissertations 


\section{CONTENTS}

Book Reviews

C. H. Cook : The English Mediaeval Parish Church ........ Otto G. von Simson

Dorothy Whitelock, ed.: English Historical Documents c. 500-1042

Allen Cabaniss

MARTIN JARRETT-KerR: Studies in Literature and Belief

Nathan A. Scott, Jr.

Dom David Knowles: The Religious Orders in England. Volume

II : The End of the Middle Ages ............................ Joseph H. Dahmus

Autobiography of Peter Cartwright Frederick A. Norwood 